\title{
La documentazione digitale del patrimonio costruito attraverso l'A-BIM. II caso studio delle Terme di Diocleziano, Roma
}

\author{
Cesare Verdoscia \\ Antonella Musicco \\ Michele Buldo \\ Riccardo Tavolare \\ Noemi Pepe
}

Abstract

Le tecnologie di gestione delle informazioni dimostrano grandi potenzialità anche nel settore dei Beni Culturali $(\mathrm{CH})$. L'arricchimento semantico di modelli digitali tridimensionali mediante l'integrazione di set di dati eterogenei è di fondamentale importanza per la loro conservazione.

La presenta ricerca, applicata al caso studio delle Terme di Diocleziano (Roma), si pone l'obiettivo di illustrare come l'approccio A-BIM (Archaeological Building Information Modeling) sia di ausilio al processo che, partendo dal rilievo del bene archeologico e dalla raccolta delle informazioni di archivio e rilievo, giunge alla realizzazione di un modello tridimensionale a tre diversi livelli di dettaglio (basso, medio, alto), contenitore di informazioni interrogabili e integrabili con l'evoluzione del bene, utilizzabili per la sua corretta gestione e conservazione.

Parole chiave

rilievo laser scanner, Archaeological Building Information Modeling, gestione informativa, documentazione beni culturali, tecnologie.

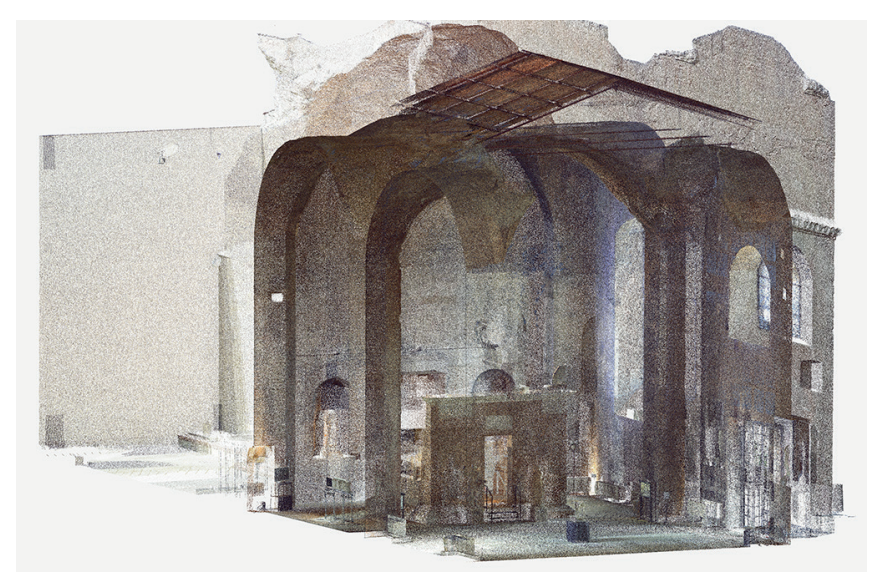




\section{Introduzione}

Nell'ambito dei beni archeologici e architettonici, le azioni di tutela sono spesso difficoltose a causa della frammentarietà dei dati raccolti, determinando criticità interpretative che si riverberano nelle attività di conservazione e successiva fruizione dei manufatti.

La costituzione di un approccio olistico, che agevoli l'analisi e la ricostruzione delle informazioni ottenuti dalla consultazione dagli archivi e dai rilievi in situ, ha un duplice obiettivo: favorire i processi di conservazione attraverso approcci integrati e superare gli ostacoli legati all'accessibilità facilitando la fruizione virtuale. Questo duplice obiettivo si traduce nell'elaborazione di modelli tridimensionali che contestualmente esprimano la qualità della figurazione realistica e l'informatizzazione semantica e gerarchica degli elementi rappresentati. Nel settore dei beni archeologici le tecnologie di rilievo tridimensionale (Scansione laser e fotogrammetria aerea e terrestre) consentono di ottenere elevati livelli di accuratezza geometrica [Bosco et al. 20 18, pp. 377-388] e l'acquisizione di ingenti porzioni territoriali in limitati periodi di tempo [Risbøl, Gustavsen, 2018, pp. 329-338]. Tali tecnologie sono oggi implementate con l'integrazione di sistemi informativi come GIS (Geographic Information System) [Brusaporci et al. 20 I2, pp. 3 I 5-322] e BIM (Building Information Modeling) [Pocobelli et al. 20I 8, pp. 23-26]. A differenza di altri sistemi informativi, nell'approccio BIM, che nell'ambito dei beni archeologici assume la denominazione A-BIM (Archaeological Building Information Modeling), la semantica dei componenti architettonici assume un nuovo significato. La rappresentazione digitale non si concentra solo sugli aspetti morfometrici, ma anche sulla modellazione informativa sulla base del set di dati acquisito in fase di rilievo o raccolto in archivi [Tomasello et al. 20 I 8, pp. I - I3; Bosco et al. 2019, pp. |65- |72]. I dati inseriti sono relazionati all'oggetto rappresentato e sono gestibili e computabili attraverso piattaforme integrate agli ambienti di modellazione mediante tre diverse modalità: I) database relazionali esportati/importati con middleware open source quali driver ODBC (Open DataBase Connectivity) o interfacce proprietarie, come GDL in ArchiCADß o MDL in Bentleyß [Eastman et al. 20 I I; Verdoscia et al. 2020, pp. I000- I008]; 2) applicativi personalizzabili e flessibili, sviluppati attraverso scripts (add-in) mediante API (Application Program Interface) [Bruno 2017]

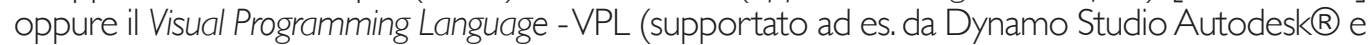
Graphisoft Grasshopper@) [Negendahl 20I5, pp. 39-53]; 3) piattaforme in cloud personalizzabili, in grado di connettere il modello tridimensionale a database relazionali di attributi statici e sensori per il monitoraggio in tempo reale [Chien et al. 20 I7, pp. 436-444]. Attraverso l'applicazione del BIM ai beni archeologici, notevoli sono i risultati che si sono ottenuti nei processi di documentazione [Capparelli, Camiz 20 I9, pp. 333-342], analisi formale [Diara, Rinaudo 2020, pp. I 38 I - I 388], conservazione e tutela [Akca et al. 2006, pp. 375-382], ricostruzione di modelli diacronici [Rodríguez-gonzálvez et al. 20 I7, pp. I -3;Templin et al. 20 I9, pp. I - I I;Verdoscia et al. 2020, pp. I000- I008], analisi strutturali [Vatan et al. 2009, pp. 659-669], applicazione di realtà virtuale [Duguleană et al. pp. I-243; Banfi 2020, pp. 16-33], di machine learning [Croce et al. 202 I , pp. I-34], analisi dello stato di conservazione [Diara, Rinaudo 2020, pp. I 38 I- I 388].

La ricerca illustra il processo di elaborazione di un modello tridimensionale informatizzato a partire da nuvole di punti LIDAR delle aule VIII, X e XI del Museo Nazionale Romano sito nelle Terme di Diocleziano (Roma), attraverso l'utilizzo dell'approccio A-BIM, implementando un collegamento dati su base relazionale. II modello geometrico è stato realizzato con tre livelli di dettaglio (basso, medio, alto) sfruttando le potenzialità della modellazione parametrica e l'estrazione automatica di superfici mesh dagli output di rilievo. Le informazioni (dati di rilievo, anagrafica monumento, localizzazione amministrativa, georeferenziazione, fonti e documenti di riferimento) strutturate e gerarchizzate in formato Microsoft Access sono stare collegate al modello BIM attraverso driver ODBC.

\section{Caso studio: Le Terme di Diocleziano (Roma)}

II complesso delle Terme di Diocleziano fu edificato in onore di Diocleziano, tra il 298 e il 306 d.C. e si sviluppava su una superficie di circa 13 ettari, nella zona compresa tra i colli Quirinale e Viminale, riproducendo lo schema derivante dai complessi termali di Traiano 


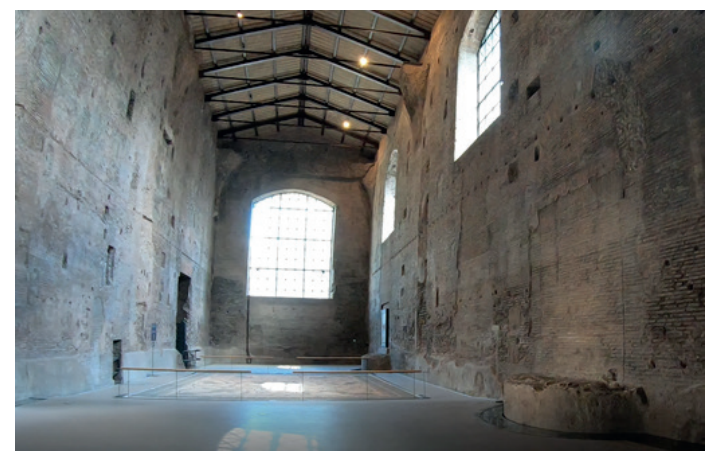

e di Caracalla. II complesso poteva contenere fino a 3000 persone ed era costituito da un edificio centrale sviluppato longitudinalmente, articolato in ambienti simmetrici rispetto all'asse mediano trasversale, ove si svolgevano le attività termali e balneari; un recinto esterno quadrangolare di circa 388 per 328 metri, completato sul lato sud-occidentale da un'esedra di circa 150 metri di diametro in cui erano collocati gli ambienti destinati ad attività culturali e ricreative e un vasto giardino che separava le due parti, con aree verdi abbellite da vasche e fontane.

L'edificio centrale era costituito da un insieme di ambienti (fig. I), inseriti in un grande quadrilatero di circa 37.200 mq. All'interno si articolavano sale dalle diverse funzioni: ingressi, vestiboli, spogliatoi, palestre, sale riscaldate tra le quali laconica e sudationes, il calidarium, il tepidarium e il frigidarium con la grande piscina. Altri ambienti erano destinati alla cura del corpo e ai massaggi. Non mancavano i punti di ristoro (thermopolia e popinae) e aree destinate agli spettacoli. In prossimità delle sale riscaldate, due vaste aree permettevano la gestione di gran parte degli impianti tecnici.

In seguito alle invasioni barbariche (VI d.C.) il complesso termale fu abbandonato e ha subito delle trasformazioni funzionali e divisioni interne tra le più note la chiesa consacrata al culto della Madonna degli Angeli e alla memoria dei martiri cristiani di Michelangelo ( 1562), la annessa Certosa, i Granari di Gregorio XIII ( 1575), la cappella dedicata a Sant'Isidoro protettore delle messi (1754). Dal 1889 ebbe inizio un processo di valorizzazione del complesso delle Terme dove oggi ha sede il Museo Nazionale Romano [Forma Urbis 2013].

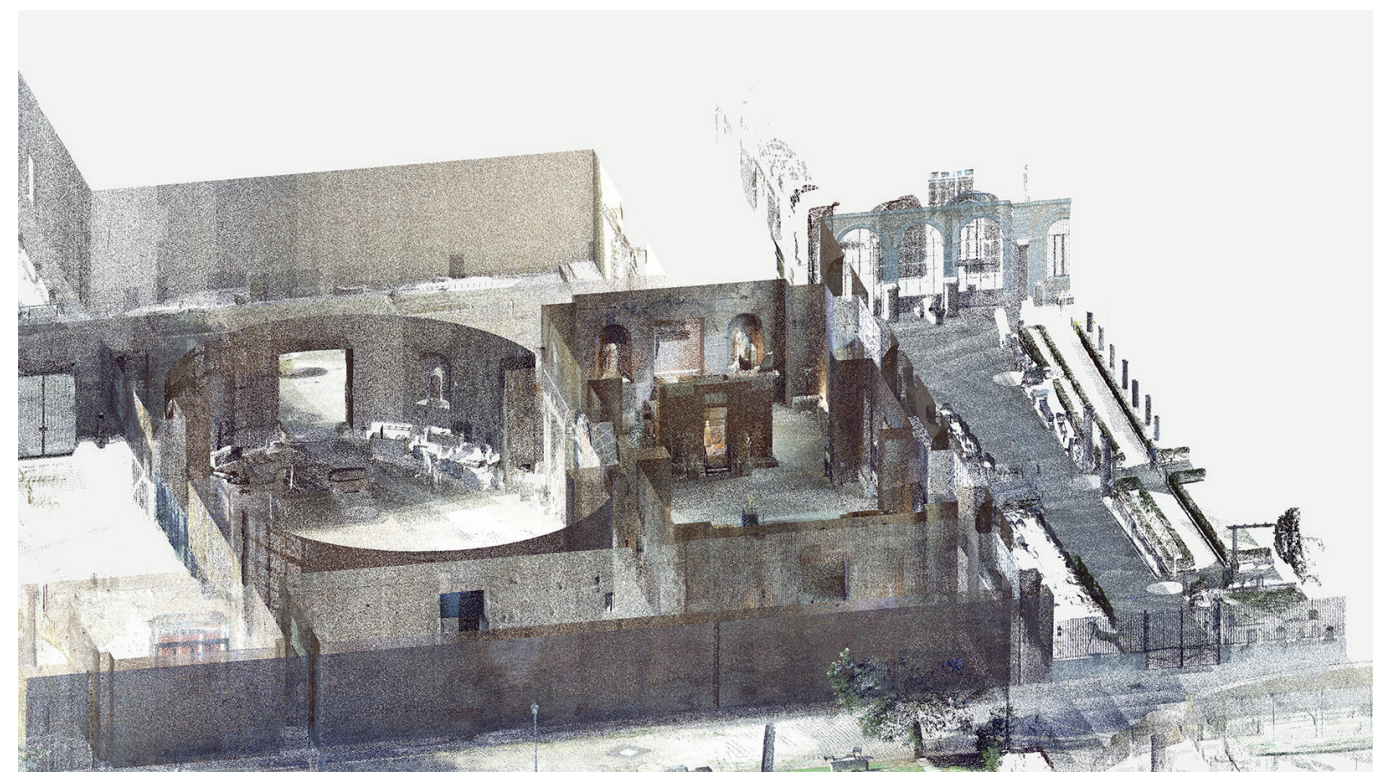




\section{Attività di rilievo}

II rilievo è stato effettuato in occasione della "Mostra Roads Of Arabia. Treasures Of Saudi Arabia" promossa dal Ministero della Cultura dell'Arabia Saudita e dal Ministero per i beni e le attività culturali e per il turismo d'Italia. In tale occasione, il rilievo è stato utilizzato per lo studio delle proposte della Direzione Artistica Alda-Fendi-Esperimenti in collaborazione con Klinamen Kloud Srl. In particolare, ha riguardato l'aula X, aula Xl e parte dell'aula VIII del Museo Nazionale Romano.

La fase operativa preliminare ha previsto redazione di un piano di acquisizione per ottimizzare il rapporto tra il numero e la risoluzione delle scansioni, il tempo di acquisizione e l'adeguata sovrapposizione. Lo strumento utilizzato è lo scanner laser Faro modello Focus 3D I 20 CAM2 le cui specifiche tecniche consentono un'accuratezza di $\pm 2 \mathrm{~mm}$, una portata da $0,6 \mathrm{~m}$ fino a $120 \mathrm{~m}$, una velocità di misurazione di 976.000 punti/secondo, un campo visivo verticale e orizzontale di $305^{\circ}$ e $360^{\circ}$, uno spot di emissione laser circolare di diametro di $3,00 \mathrm{~mm}$. Data l'estensione degli ambienti di interesse, circa $300 \mathrm{mq}$, è stato necessario realizzare n. 45 acquisizioni, con una risoluzione variabile tra 6,0 e 7,5 $\mathrm{mm}$ ad una distanza di IOm, di circa 30 Mpt a scansione, garantendo una risoluzione minima di 8248×34I4 pt ed una massima di $10310 \times 4268$ pt.
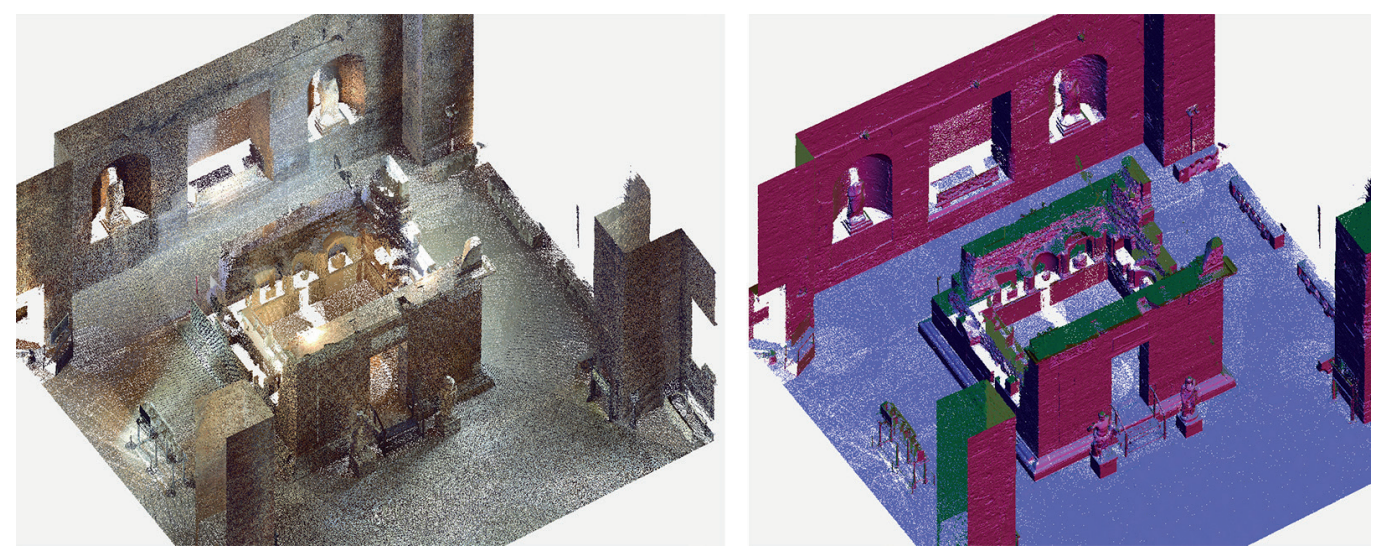

\section{Elaborazione della nuvola di punti e segmentazione geometrica}

L'elaborazione digitale delle scansioni è stata svolta con l'ausilio dei software Autodek Recap Pro ${ }^{\circledR}$ e CloudCompare. Le nuvole di punti di ogni singola scansione sono state controllate, pulite dai dati superflui, allineate e fuse tra loro per ottenere un'unica ricostruzione tridimensionale di circa 950 MPt. Questa è stata sottoposta a ricampionamento e decimazione ottenendo una riduzione a circa 550 Mpt (fig. 2).

Attraverso un processo di segmentazione parametrica allinterno di un offset di $10 \mathrm{~cm}$, identificando 8 punti complanari, sono state estratti i componenti architettonici (muri, volte, colonne, apparati decorativi). Si è ottenuta una prima identificazione degli elementi da utilizzare come riferimento per la modellazione delle famiglie parametriche in Autodesk Revit ${ }^{\circledR}$ per elaborare la relativa mesh tridimensionale (fig. 3).

\section{Modellazione geometrica e informatizzazione del modello A-BIM}

La modellazione degli elementi architettonici in ambiente BIM è un'attività molto critica. La parametrizzazione geometrica degli elementi architettonici è spesso molto complessa. Attualmente non esistono processi automatici o applicazioni che possono realizzare un passaggio diretto dalla nuvola di punti ai modelli BIM completi. Sulla base delle caratteristiche dell'edificio o del manufatto 
Fig. 4. Modello A-BIM completo del complesso termale.

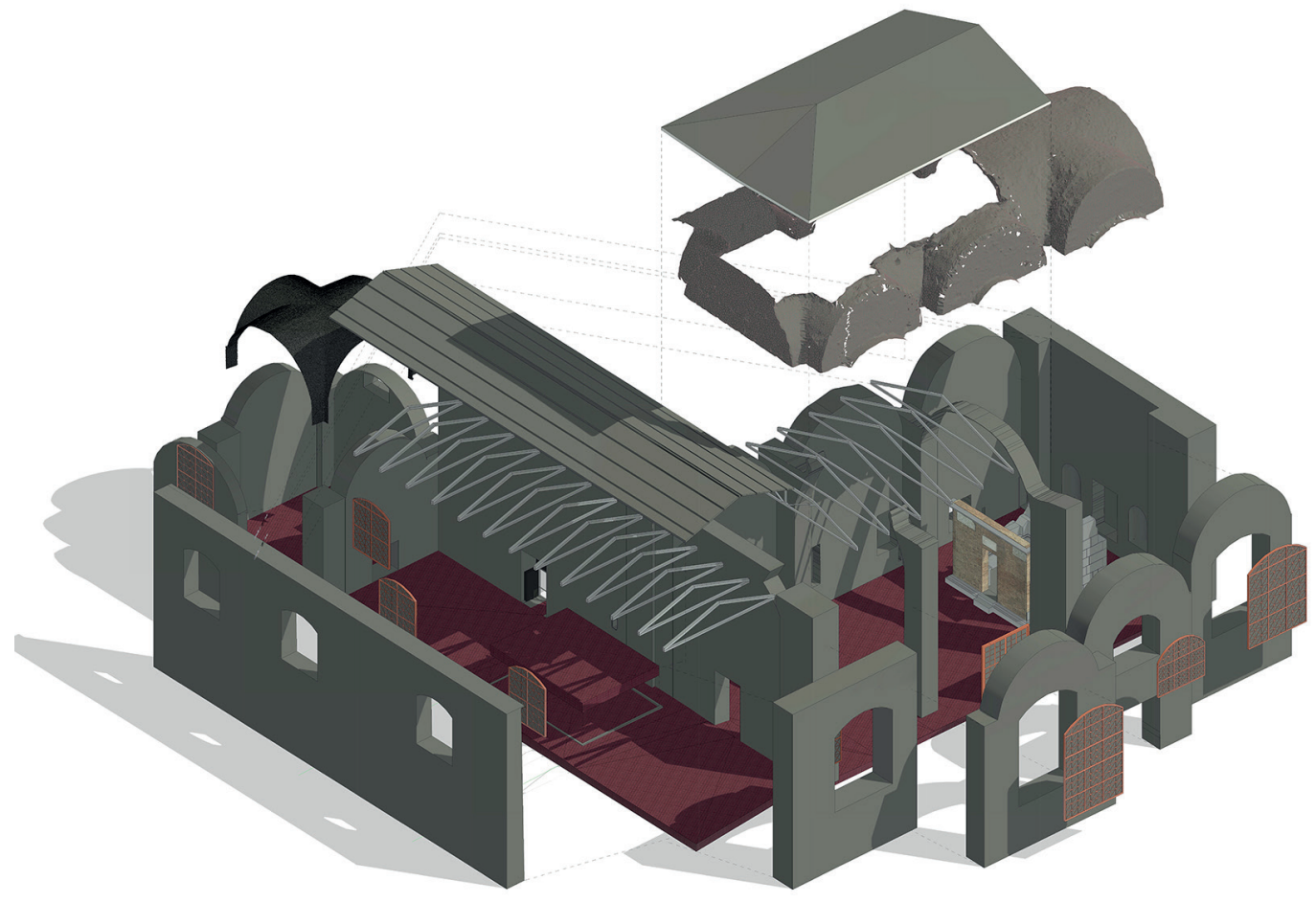

è necessario definire un livello di dettaglio (LoD) appropriato per riprodurre un modello simile all'originale, il cui LoD dipende direttamente dalla raccolta dei dati e dai diversi obiettivi operativi previsti. In questo lavoro il modello tridimensionale è stato creato a partire dalla nuvola di punti ricampionata minimizzando il numero di step, evitando perdite di accuratezza, qualità di dati e dettagli e tenendo conto delle regole costruttive e dei rapporti di proporzionalità delle forme. Questo approccio multi LoD oltre a consentire una discretizzazione geometrica personalizzabile, consente di programmare la visibilità e quindi la rappresentazione degli oggetti in funzione delle effettive necessità di utilizzo.

Considerata la finalità A-BIM del modello, per l'involucro edilizio è stata scelta una modalità di modellazione locale, che privilegiasse la forma alla scalabilità informativa. In particolare, si sono modellate separatamente le parti relative al mosaico di Ercole e Acheloo presenti nell'aula IX e la Tomba dei Platorini, elaborando per quest'ultimo il collegamento informativo tramite gli schemi dati relazionali.

Per gli elementi di forma irregolare costituenti i resti della copertura a botte dell'aula $X \mathrm{e}$ della volta a crociera presente nel locale attiguo all'aula XI si è scelto di costituire una fami-

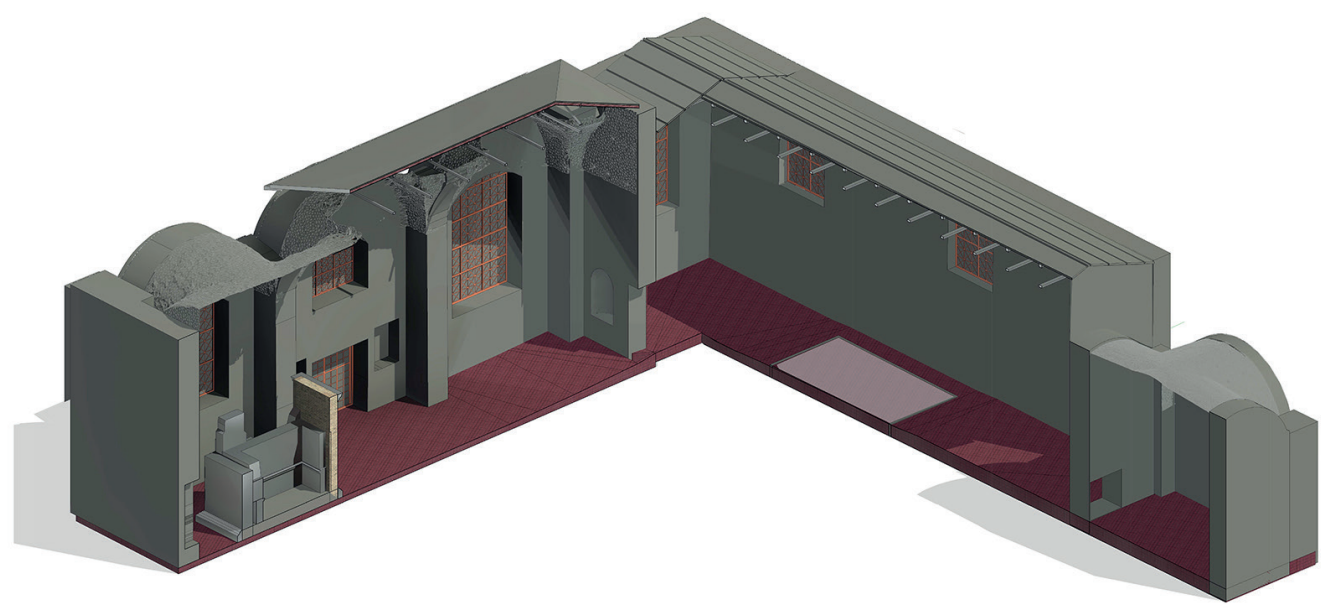


Fig. 6. Rappresentazione e compositing a livelli di dettaglio differenti (basso medio e alto) della famiglia Revit della Tomba dei Platorini.
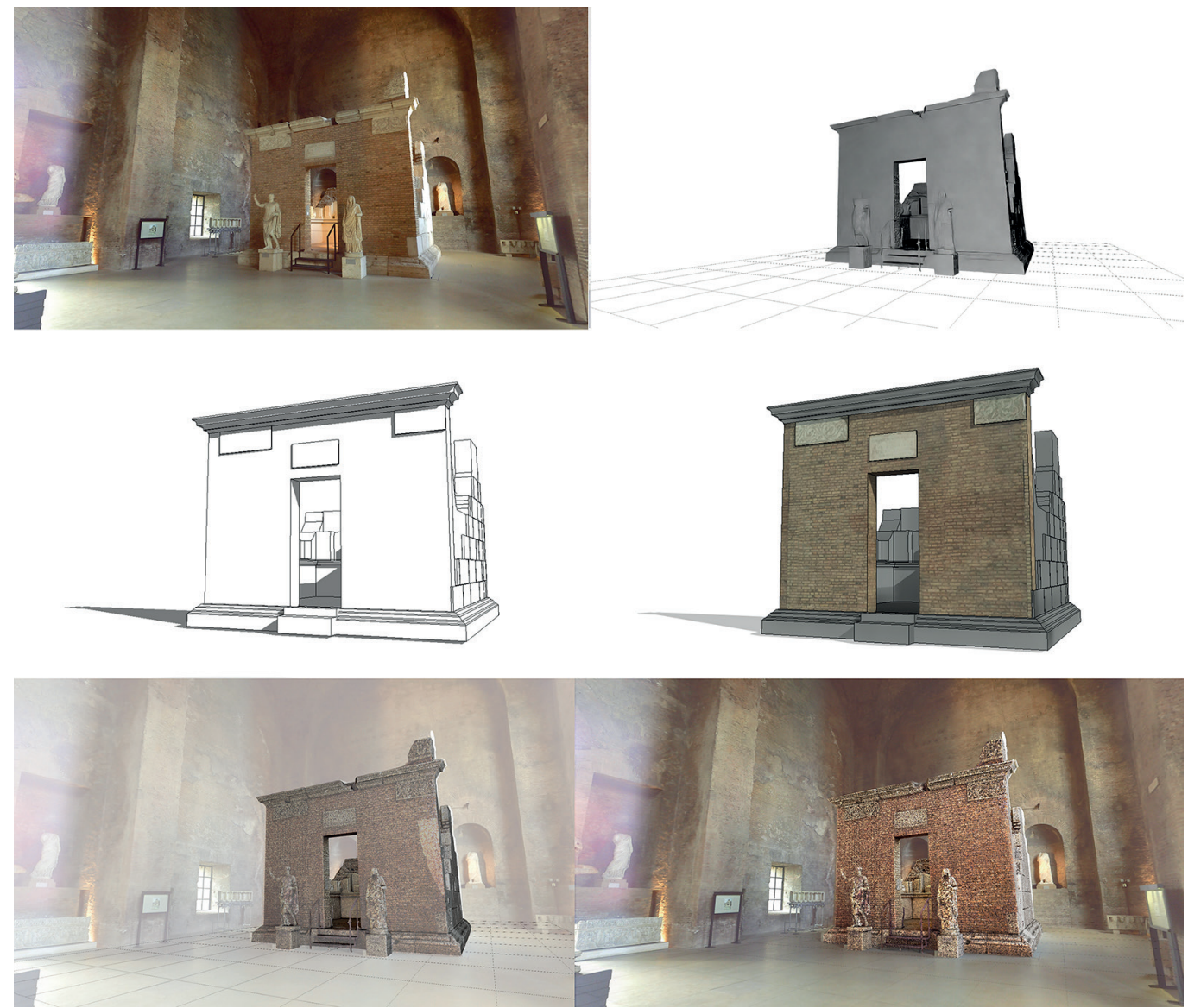

glia caricabile contenente una ricostruzione poligonale basata sulla nuvola di punti LIDAR tramite l'applicazione dell'algoritmo ball-pivoting [Bernardini, Claudio 1999, pp. 349-359], in modo da lasciare inalterata la morfologia irregolare di tali elementi incompleti (figg. 4, 5).

Per la Tomba dei Platorini, invece, si sono identificati gli elementi volumetrici costituenti il sepolcro, progettando all'interno di una stessa famiglia caricabile tre versioni rappresentative dello stesso elemento, attivabili tramite apposita proprietà di vista all'interno del programma di BIM Authoring Revit ${ }^{\circledR}$.

Nello specifico, impostando una vista con livello di dettaglio basso, le geometrie della famiglia appaiono create tramite modelli locali ricavati da generatrici poligonali. Tali elementi pur conservando una separazione formale che consente l'attribuzione di eventuali parametri informativi specifici, mantiene una elevata semplificazione rappresentativa.

Impostando invece una modalità di dettaglio media, la famiglia caricata visualizza una texturizzazione degli strati esterni dei volumi. Tale texture è stata ottenuta tramite l'elaborazione di una mappatura RGB estrapolata dalla matrice dei punti e ottimizzata tramite lo studio delle coordinate UV locali, in modo da preservare la riconoscibilità materica e stilistica degli oggetti. Infine, applicando la proprietà di dettaglio elevata, il software mostra automaticamente una terza versione della Tomba, ricavata tramite la ricostruzione di una mesh poligonale ricavata direttamente dalla nuvola di punti, a seguito di un processo di decimazione e ottimizzazione elaborata con l'ausilio dei software CloudCompare e MeshLab (fig. 6).

La valutazione delle informazioni descrittive da inserire all'interno del modello A-BIM (fig. 7) è stata svolta a partire dalle schede informative del Catalogo Generale dei Beni Culturali implementate con dati riguardanti il rilievo, a file multimediali e ricostruzioni mesh tridimensionali. Le informazioni inserite riguardano: l'anagrafica dell'oggetto (denominazione, localizzazione, tipologia, funzione, etc.), la localizzazione geografico amministrativa (Stato, Regione, indirizzo, etc.), la georeferenziazione (denominazione scavo, periodo, etc.), la cronologia (fascia cronolo- 
Fig. 7. Informazioni descrittive inserite allinterno del database associato al modello A-BIM.
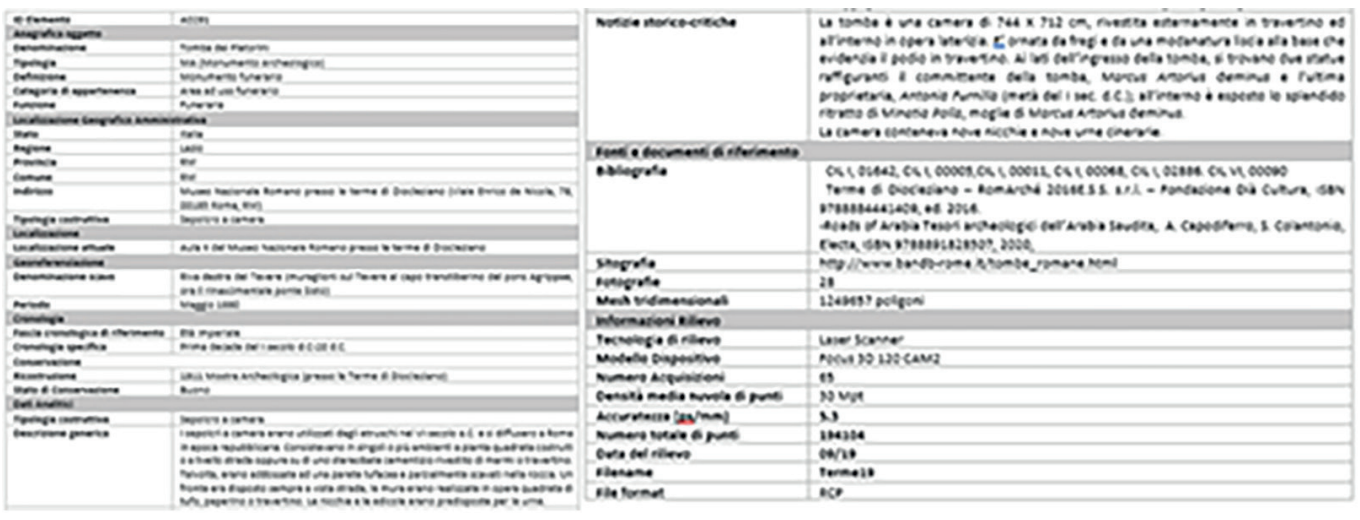

gica di riferimento, cronologia specifica, ricostruzione, stato di conservazione, etc.), dati analitici (tipologia crostruttiva, descrizione generica, notizie storico critiche), fonti e documenti di riferimento (bibliografia, sitografia, mesh tridimensionale etc.), dati di rilievo (tecnologia utilizzata, modello dispositivo, numero di acquisizioni, etc.)

La progettazione delle relazioni informative tra modello e database si è svolta tramite l'ausilio dell'interfaccia ODBC (Open DataBase Connectivity), in modo da garantire un'astrazione applicativa indipendente dai linguaggi di programmazione dati, collegando il progetto di Autodesk Revit ${ }^{\circledR}$ ad un database in formato Microsoft Access $^{\circledR}$, strutturato in tabelle e relazioni concepite sulla base degli schemi di catalogazione gerarchici in formato XSD (fig. 8).

Tale approccio, oltre a consentire un'organizzazione informativa standardizzata, interfacciabile eventualmente con software specifici, permette una strutturazione indicizzata delle risorse testuali, grafiche e più in generale, informative. II collegamento tra il singolo elemento del modello 3D e la base informativa, avviene tramite un parametro ID richiamabile tramite query SQL, garantendo in questo modo la scalabilità e la eventuale personalizzazione del reperimento dei dati.

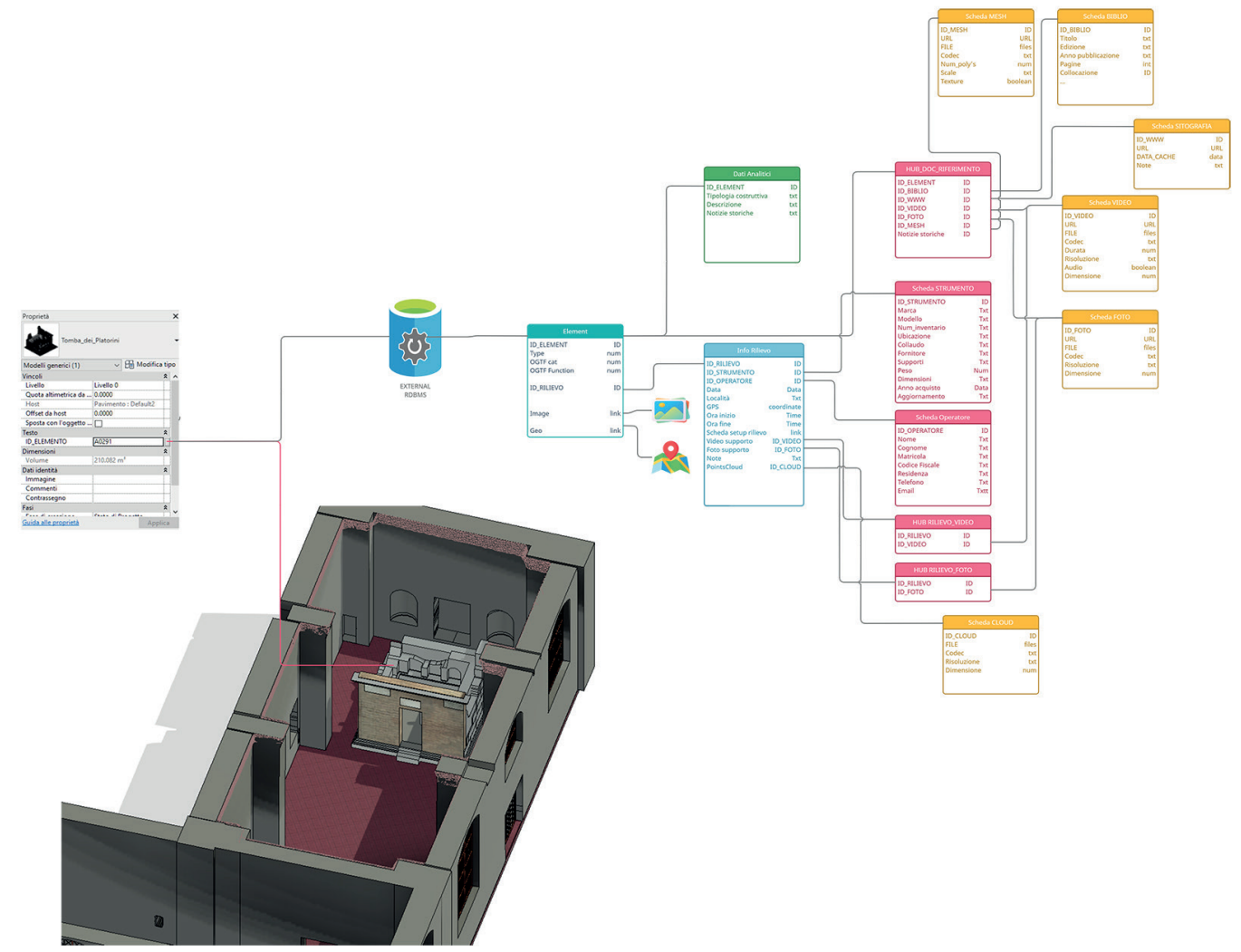


II modello BIM diventa così 'hub' di accesso e lettura di tutte le fonti attribuibili, tramite un'organizzazione dei dati gerarchica che offre anche una efficiente gestione dello spazio di archiviazione consentendo il riutilizzo dei files (un singolo file può risultare attribuito a più oggetti del modello) ed il salvataggio multipiattaforma (i file possono risultare salvati su hard-disk locali, NAS o sul WEB) (fig. 9).

\section{Conclusioni}

Nell'articolo si è illustrata l'implementazione di un modello tridimensionale attraverso approccio A-BIM di una porzione delle Terme di Diocleziano, caratterizzata da irregolarità ed eterogeneità morfologica. Si è valutato come l'A-BIM sia una metodologia affidabile per la rappresentazione del patrimonio costruito poiché associa l'alta qualità del modello a una geometria accurata realizzabile a diversi livelli di dettaglio e a un collegamento a data set di diversa natura grazie alla sua struttura fondata su database relazionali.

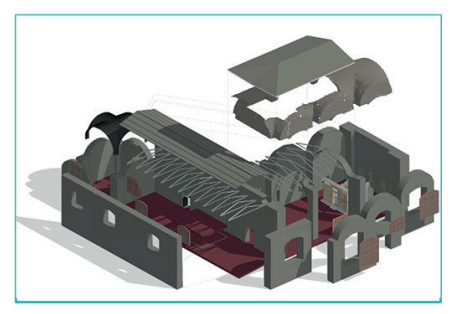

REVIT BIM FILE

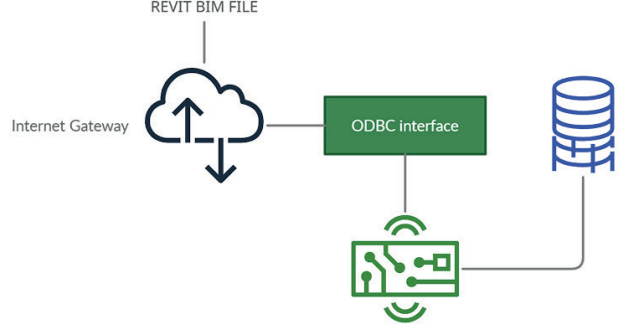

API Runtime

DB Engine
Locale

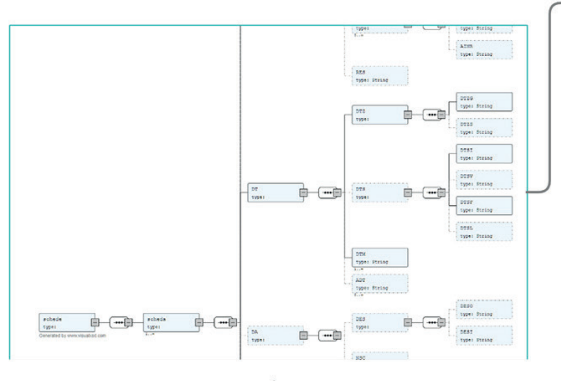

XSD Schema

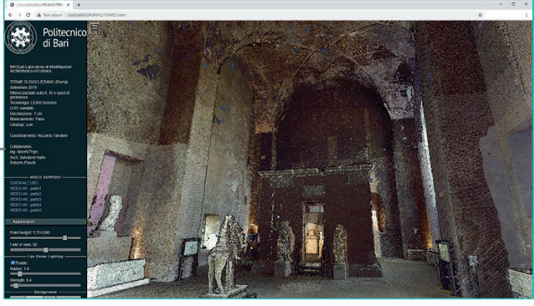

Web-based points cloud viewer

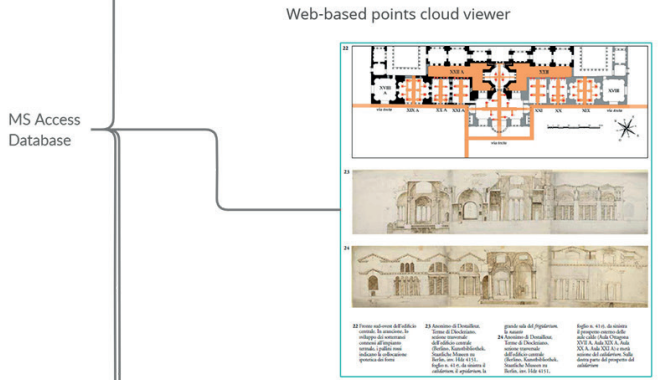

Documents

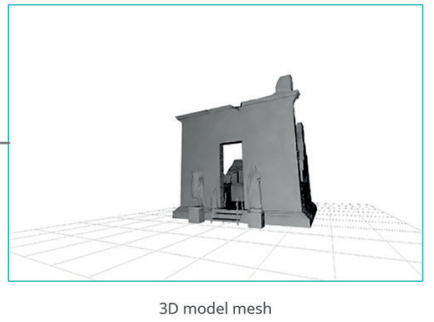

3D model mesh

Riferimenti bibliografici

Akca D., Remondino F., Novák D., Hanusch T., Schrotter,G., Gruen A. (2006). Recording and modeling of cultural heritage objects with coded structured light projection systems. In 2nd International Conference on Remote Sensing in Archaeology, March 20I5, pp. 375-382.

Banfi F. (2020). HBIM, 3D drawing and virtual reality for archaeological sites and ancient ruins. In Virtual Archaeology Review, II (23), pp. I6-33.

Bernardini F., Claudio S. (1999). The Ball-Pivoting Algorithm for Surface Reconstruction. In IEEE TRANSACTIONS ON VISUALIZATION AND COMPUTER GRAPHICS, pp. 349-359. 
Bosco A., D'Andrea A., Nuzzolo M., Pirelli R., Zanfagna P. (20 I 8). A Virtual Reconstruction of the Sun Temple of Niuserra: from Scans to ABIM Angela. In Oceans of Data Proceedings of the 44th Conference on Computer Applications and Quantitative Methods in Archaeology, pp. 377-388.

Bosco A., D'Andrea A., Nuzzolo M., Zanfagna P. (2019). A BIM APPROACH for the ANALYSIS of AN ARCHAEOLOGICAL MONUMENT. In ISPRS Annals of the Photogrammetry. Remote Sensing and Spatial Information Sciences, 42(2/W9), pp. I65- I 72.

Bruno N. (2017). From Survey To Analysis for Cultural Heritage Management: A New Proposal for Database Design in Bim.

Brusaporci S., Centofanti M., Continenza R., Trizio I. (2012). Sistemi Informativi Architettonici per la gestione, tutela e fruizione dell'edilizia storica. In ATTI $16^{\circ}$ Conferenza Nazionale ASITA 20 I 2, pp. 315-322.

Capparelli F., Camiz A. (2019). Bim Documentation for Architecture and Archeology: the Shipwreck Museum in the Kyrenia Castle, Cyprus. pp. 333-342. Roma: Gangemi Editore.

Chien S., Chuang T., Yu H.-S., Han Y., Soong B. H., Tseng K. J. (2017). Implementation of Cloud BIM-based Platform Towards High-performance Building Services. In Procedia Environmental Sciences, 38, pp. 436-444.

Croce V., Caroti G., De Luca L., Jacquot K., Piemonte A., Véron P. (202I). From the semantic point cloud to heritage-building information modeling: A semiautomatic approach exploiting machine learning. In Remote Sensing, I3(3), pp. I-34.

Diara F., Rinaudo F. (2020). Building archaeology documentation and analysis through open source HBIM solutions via nurbs modelling. In International Archives of the Photogrammetry, Remote Sensing and Spatial Information Sciences - ISPRS Archives, 43(B2), pp. $1381-1388$.

Duguleană M., Carrozzino M., Gams M., Tanea I. (2018).VR Technologies in Cultural Heritage Communications in Computer and Information Science (Vol. 904), pp. I-245.

Eastman C.M.C., Teicholz P., Sacks R., Liston K. (20I I). BIM Handbook: A Guide to Building Information Modeling for Owners Managers, Designers, Engineers and Contractors (2nd Ed). John Wiley \& Sons, Inc. Hoboken, USA: John Wiley \& Sons Inc

Forma Urbis (maggio 2016). Il Museo Nazionale Romano alle Terme di Diocleziano. RomArché 20 I6. Editoriale \& Sommario.

Negendahl K. (20I5). Building performance simulation in the early design stage: An introduction to integrated dynamic models In Automation in Construction, 54, pp. 39-53.

Pocobelli D.P., Boehm J., Bryan P., Still J., Bové J.G. (20 I 8). BIM for heritage science : a review. In Heritage Science, pp. 23-26.

Risbø| O., Gustavsen L. (20।8). LiDAR from drones employed for mapping archaeology - Potential, benefits and challenges. In Archaeological Prospection, 25(4), pp. 329-338.

Rodríguez-gonzálvez P., Muñoz-nieto A.L., Sanchez-Aparicio L.J. (20 17). 4D reconstruction and visualization of cultural heritage : analyzing our legacy through time. In The International Archives of the Photogrammetry, Remote Sensing and Spatial Information Sciences, XLII (March), pp. I-3.

Templin T., Brzezinski G., Rawa M. (2019). Visualization of Spatiooral Building Changes Using 3D Web GIS. In IOP Conference Series: Earth and Environmental Science, 22I ( ), pp. I- I I.

Tomasello N., Cascone S.M., Russo G. (20I8). BIM for archaeological heritage : the case study of the Terme Romane dell' Indirizzo of Catania. June, pp. I- I3

Vatan M., Selbesoglu M., \& Bayram B. (2009). The use of 3D laser scanning technology in preservation of historical structures. In Wiadomosci Konserwatorskie, 44, pp. 659-669.

Verdoscia C., Mongiello G., Musicco A., Tavolare R., Salomone A. (2020). 4D-HBIM for the conservation and valorization of cultural heritage. In World Heritage and Contamination, pp. I000- 1008.

<http:/www.catalogo.beniculturali.it> (consultato il 23 Febbraio 2021)

\section{Autori}

Cesare Verdoscia, Politecnico di Bari, cesare.verdoscia@poliba.it

Antonella Musicco, Politecnico di Bari, antonella.musicco@poliba.it

Michele Buldo, Politecnico di Bari, michele.buldo@poliba.it

Riccardo Tavolare, Politecnico di Bari, riccardo.tavolare@poliba.it

Noemi Pepe, Politecnico di Bari, pepenoemil@gmail.com

Per citare questo capitolo:Verdoscia Cesare, Musicco Antonella, Buldo Michele, Tavolare Riccardo, Pepe Noemi (202I). La documentazione digitale del patrimonio costruito attraverso l' A-BIM. II caso studio delle Terme di Diocleziano, Roma/The Digital Documentation of Cultural Heritage through A-BIM. The Case Study of the Baths of Diocletian, Rome. In Arena A. Arena M. Mediati D. Raffa P. (a cura di). Connettere. Un disegno per annodare e tessere Linguagoi Distanze Tecnologie. Atti del $42^{\circ}$ Convegno Internazionale dei Docenti delle Discipline della Rappresentazione/Connecting Drawing for weaving relationship. Languages Distances Technologies. Proceedings of the 42 th Internotional Conference of Representation Disciplines Teachers. Milano: FrancoAngeli, pp. 2686-2703. 


\title{
The Digital Documentation of Cultural Heritage through A-BIM. The Case Study of the Baths of Diocletian, Rome
}

\author{
Cesare Verdoscia \\ Antonella Musicco \\ Michele Buldo \\ Riccardo Tavolare \\ Noemi Pepe
}

Abstract

Information management technologies have shown a great potential in the field of Cultural Heritage $(\mathrm{CH})$. Enriching three-dimensional digital models with heterogeneous data sets appears to be very important for heritage preservation.

The present research, concerning the Baths of Diocletian (Rome), pursues the aim of showing how the A-BIM approach (Archaeological Building Information Modeling) can be useful during the entire preservation process: from the survey site and the collection of archive information of an archeological, to the creation of a three-dimensional model with three different levels of detail (low, medium, high), capable of conveying information that can be accessed easily and integrated along with the evolution of the architectural asset, thus helping both the management and the conservation procedures.

Keywords

laser scanner survey, Archaeological Building Information Modeling, information management, cultural heritage documentation, technologies.

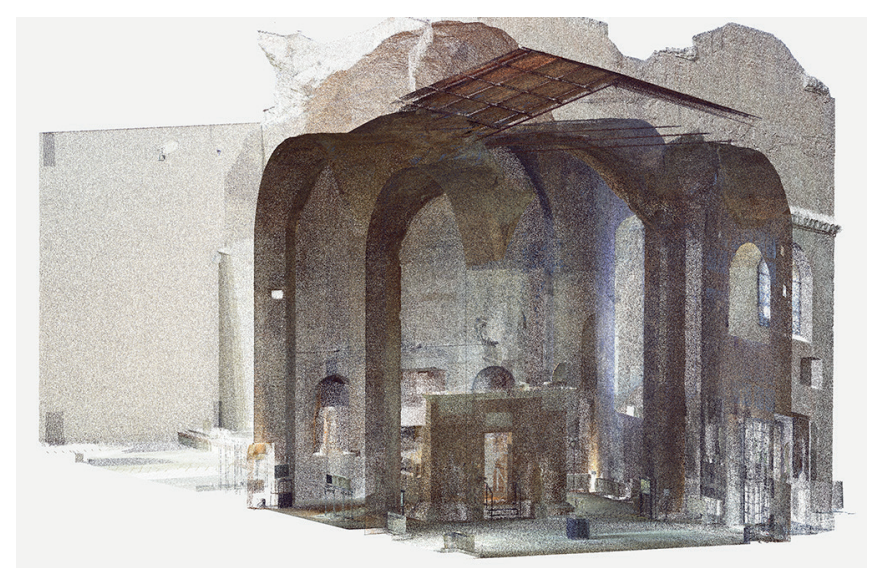




\section{Introduction}

In the field of archeological and architectural assets, restoration works are often difficult because the data collected are extremely fragmented. This phenomenon often results in interpretational issues that can affect the preservation first and the fruition of the artefacts later. In this context, the construction of a holistic approach, capable of both facilitating the analysis and the reconstruction of the information obtained by consulting archives and making on-site surveys, pursues a dual objective: in the first place it is intended to help the preservation procedures by means of integrated approaches, in the second place it wants to overcome the obstacles linked to accessibility thanks to virtual reality. This dual objective leads to the creation of a three-dimensional model that provides at the same time a realistic representation and a semantic and hierarchical computerization of the elements represented. Applied to archaeological assets, technologies for three-dimensional survey (Laser scanner and aerial and terrestrial photogrammetry) give the possibility to obtain high levels of geometric accuracy [Bosco et al. 20 18, pp. 377-388] and acquire large portions of land in a short time [Risbøl, Gustavsen 2018, pp. 329-338].

Nowadays, these technologies have been successfully implemented with information systems such as GIS (Geographic Information System) [Brusaporci et al. 20 I2, pp. 3 I5-322], and BIM (Building Information Modeling) [Pocobelli et al. 20 I8, pp. 23-26]. In contrast to other information systems, in the BIM approach, in archaeological field A-BIM (Archeological Building Information Modeling), the semantic of architectural assets acquires a new meaning. Indeed, the digital representation is not merely focused on morphometric aspects, but also on the datasets acquired during surveys or collected in archives [Tomasello et al. 20 I 8, pp. I - I 3][Bosco et al. 2019, pp. 165-172]. The data entered are connected to the objects represented and can be managed and computed in platforms integrated with the modeling environment in three different ways: I) relational databases exported/imported with an open source middleware, such as ODBC drivers (Open DataBase Connectivity) or a proprietary software, such as GDL in ArchiCAD® or MDL in Bentley ${ }^{\circledR}$ [Eastman et al. 201 I; Verdoscia et al. 2020, pp. I000-।008]; 2) Customizable and flexible applications, developed through scripts (add-in), API (Application Programming Interface) [Bruno 20 I7] or Visual Programming Language VPL (supported for instance by Dynamo Studio Autodesk $®$ and Graphisoft Grasshopper $($ ) [Negendahl 20 I5, pp. 39-53]; 3) Customizable cloud platforms, capable of creating connections between the three-dimensional model and the relational databases of static attributes and sensors for a real time monitoring [Chien et al. 20 I7, pp. 436-444].

The application of BIM to archeological assets have shown remarkable results in the documentation process [Capparelli, Camiz 20 19, pp. 333-342], in formal analysis [Diara, Rinaudo 2020, pp. I 38 | - | 388], interventions of preservation and conservation [Akca et al. 2006, pp. 375-382], the reconstruction of diachronic models [Rodríguez-gonzálvez et al. 20 I7, pp. I-3] [Templin et al. 2019, pp. I - I ], structural analysis [Vatan et al. 2009, pp. 659-669], virtual reality [Duguleană et al. 20 I8; Banfi 2020, pp. 16-33], machine learning applications [Croce et al. 202I, pp. I-34] and the analysis of the state of conservation [Diara, Rinaudo 2020, pp. I 38 I - I388].

The present work shows the making of a computerized three-dimensional model of the rooms VIII, X and XI of the National Roman Museum, located in the Baths of Diocletian (Rome). We started the building of the model from a LIDAR point cloud obtained using an A-BIM approach, later implemented with a relational-based data link. We built a geometric model with three levels of details (low, medium, high), by exploiting the potential of parametric modeling and extracting automatically the mesh surfaces from the survey outputs. We structured and hierarchized the information (data, administrative location, georeferencing, sources and reference documents) in Microsoft Access, and then we connected them to the BIM model by means of ODBC driver.

\section{Case study: The Baths of Diocletian (Rome)}

The complex of the Baths of Diocletian was built in honour of the Emperor Diocletian between 298 and 306 A.D. by reproducing the pattern deriving from the thermal complexes 


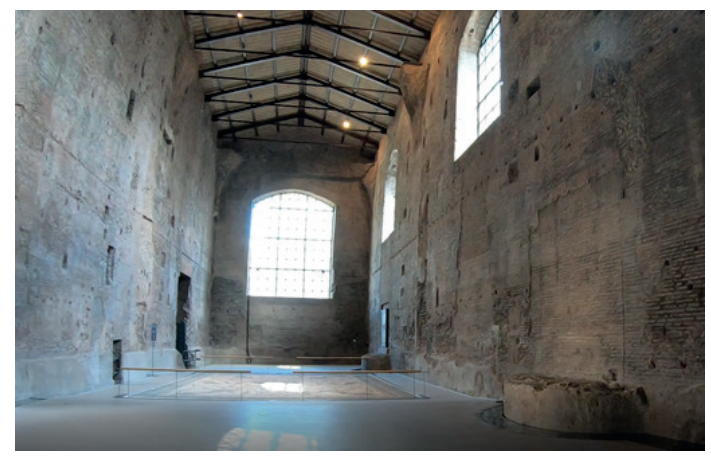

of Trajan and Caracalla over an area of 13 hectares located between the Quirinal and the Viminal Hills. The complex could host up to 3000 people and consisted in: a central building, developed longitudinally and divided into rooms arranged symmetrically with respect to the transversal median axis, where the thermal activities usually took place; a quadrangular outer settlement of about $388 \times 328$ meters, completed on its south-western part by an exedra with a diameter of 150 meters, that hosted the rooms destined to cultural and recreative activities; and a large garden, that separated the previous places with green areas embellished by pools and fountains.

The central building consisted in a set of rooms (fig. I), placed in a large quadrilateral of about 37.200 square meters. It hosted rooms with different functions: entrances, vestibules, changing rooms, gyms, heated rooms like laconica and sudationes, the calidarium, the tepidarium and the frigidarium with a big swimming pool. Other rooms were intended for body care and massages. There were also some eateries (thermopolia and popinae) and areas for shows. In proximity to the heated rooms, two large areas were reserved to the technical equipment.

After the barbaric invasions (VI A.C.), the thermal complex was dismissed and underwent some functional and spatial transformations. In particular, they concerned: the church devoted to the worship of Our Lady of the Angels and the memory of the Christian martyrs decorated by Michelangelo ( I 562); the annexed Charterhouse ( I 754); Gregorio XIII's granaries; and the chapel dedicated to Saint Isidor, protector of the harvests (1754). In 1889 the thermal complex was enhanced with the foundation of the National Roman Museum [Forma Urbis 2013].
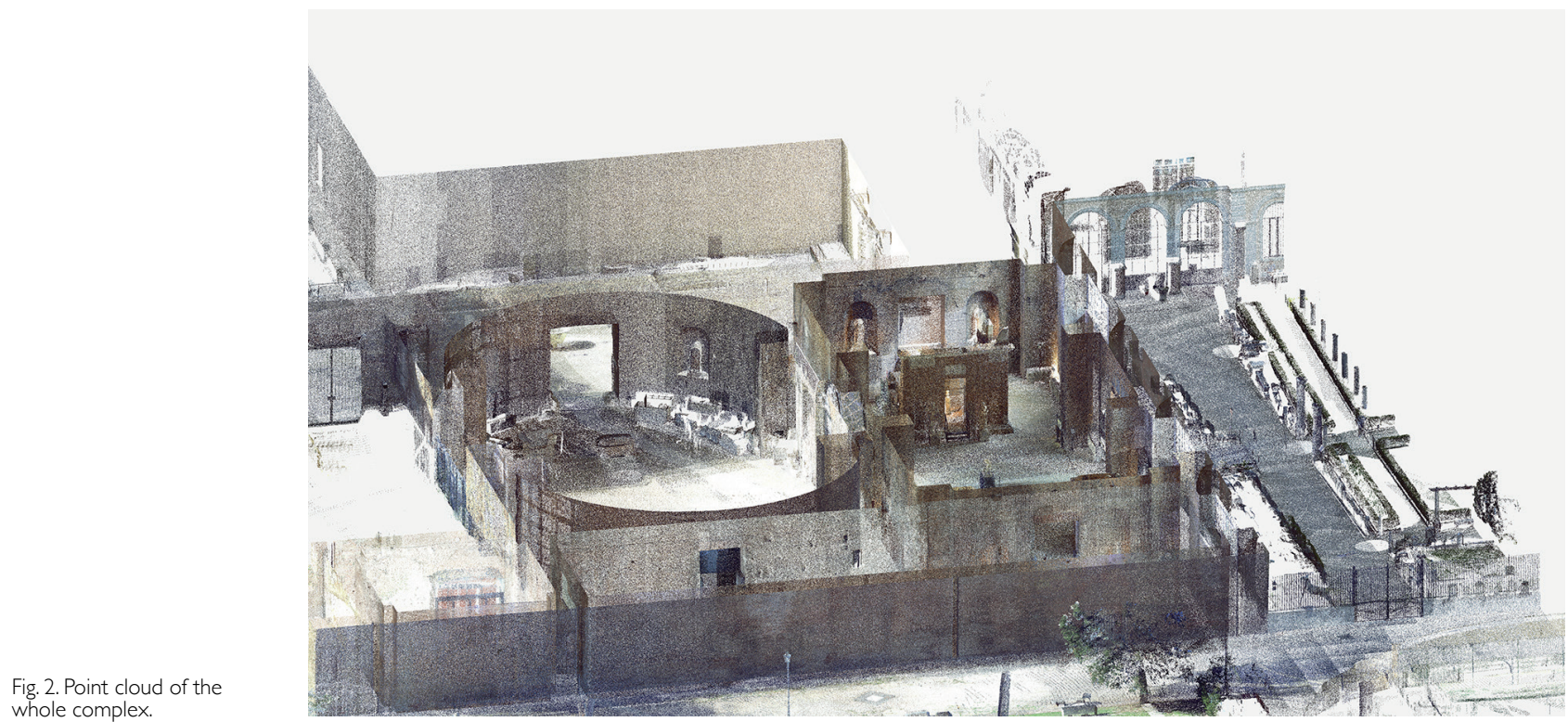


\section{The survey}

The survey has been carried out in occasion of the exposition "Roads of Arabia. Treasures of Saudi Arabia", promoted by the Ministry of Culture of Saudi Arabia and the Ministry of Cultural Heritage and Activities and Tourism of Italy (MiBACT). The survey was functional to examine the proposals put forward by the Alda-Fendi-Esperimenti Artistic Direction, in collaboration with Klinamen Cloud Srl. In particular, it covered the rooms X-XI and a part of room VIII of the National Roman Museum.

The preliminary operational phase consisted in the creation of an acquisition plan to optimise the ratio between the quantity of the scans and their resolution, the acquisition time and an adequate overlap. Laser scanner Faro model Focus 3D I 20 CAM2 has been used, whose specifications guarantee an accuracy of $\pm 2 \mathrm{~mm}$, a range from $0.6 \mathrm{~m}$ to $120 \mathrm{~m}$, a measurement speed of 976000 points per second, a vertical and horizontal plain sight of $305^{\circ}$ and $360^{\circ}$, a circular laser spot with a diameter of $3.00 \mathrm{~mm}$. Given the extension of the areas of interest, which was about 300 square meters, we decided to take 45 acquisitions, with a resolution variable between 6.0 and $7.5 \mathrm{~mm}$ at a distance of $10 \mathrm{~m}$, with about 30 Mpt per scan, guaranteeing a minimum resolution of $8248 \times 3414$ pt and a maximum resolution of $10310 \times 4268 \mathrm{pt}$.
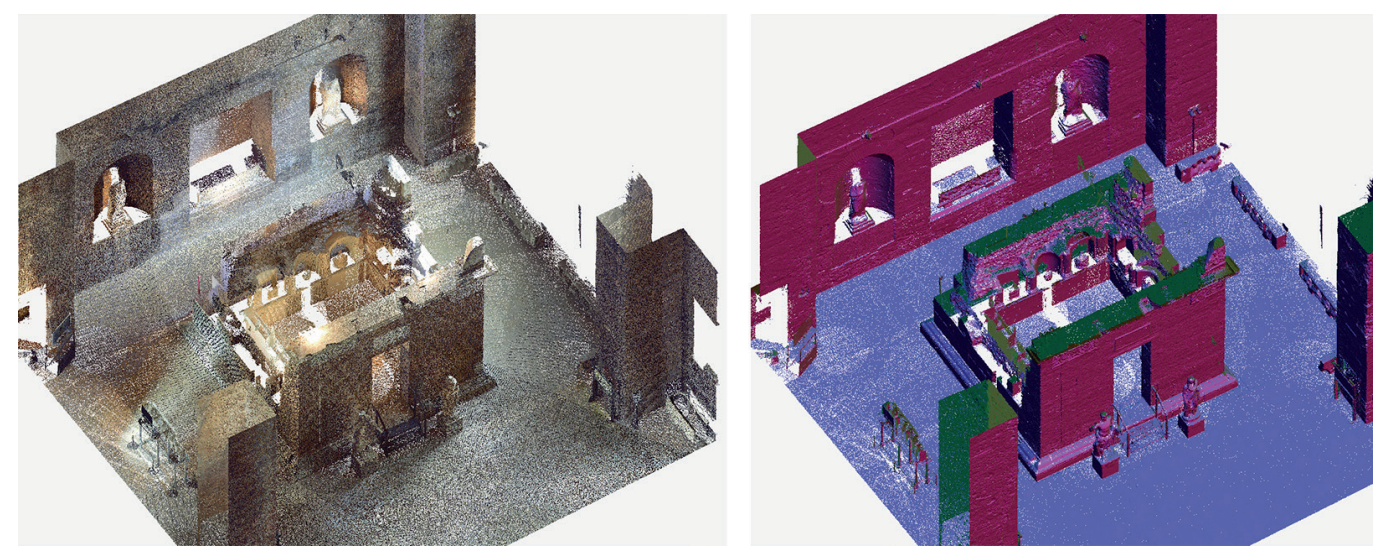

\section{Point cloud processing and geometric segmentation}

Scan have been processed by means of two software: Autodesk Recap Pro ${ }^{\circledR}$ and CloudCompare. The point clouds derived from each scan have been checked, and after removing the superfluous data, they have been aligned and merged together in order to to obtain a unique three-dimensional reconstruction of about 950 Mpt. Later the resulting point cloud was resampled and decimated, thus obtaining a reduction to approximately $550 \mathrm{Mpt}$ (fig. 2). The architectural elements (walls, vaults, columns, decorations) have been extracted in an offset of $10 \mathrm{~cm}$, after having identified 8 coplanar points, thanks to a process of parametric segmentation. In this way, firstly the elements were identified witch had to be used as a reference to model the parametric families in Autodesk Revit ${ }^{\circledR}$ and then obtained a three-dimensional mesh (fig. 3).

\section{Geometric modelling and data management in A-BIM model}

Modeling architectural elements in BIM is always extremely difficult. The geometric parametrization of architectural elements is sometimes complex activity. Nowadays there are no automated processes or programs that can directly transform a point cloud into a complete BIM model. According to the characteristics of the buildings, or the artefacts, it is neces- 


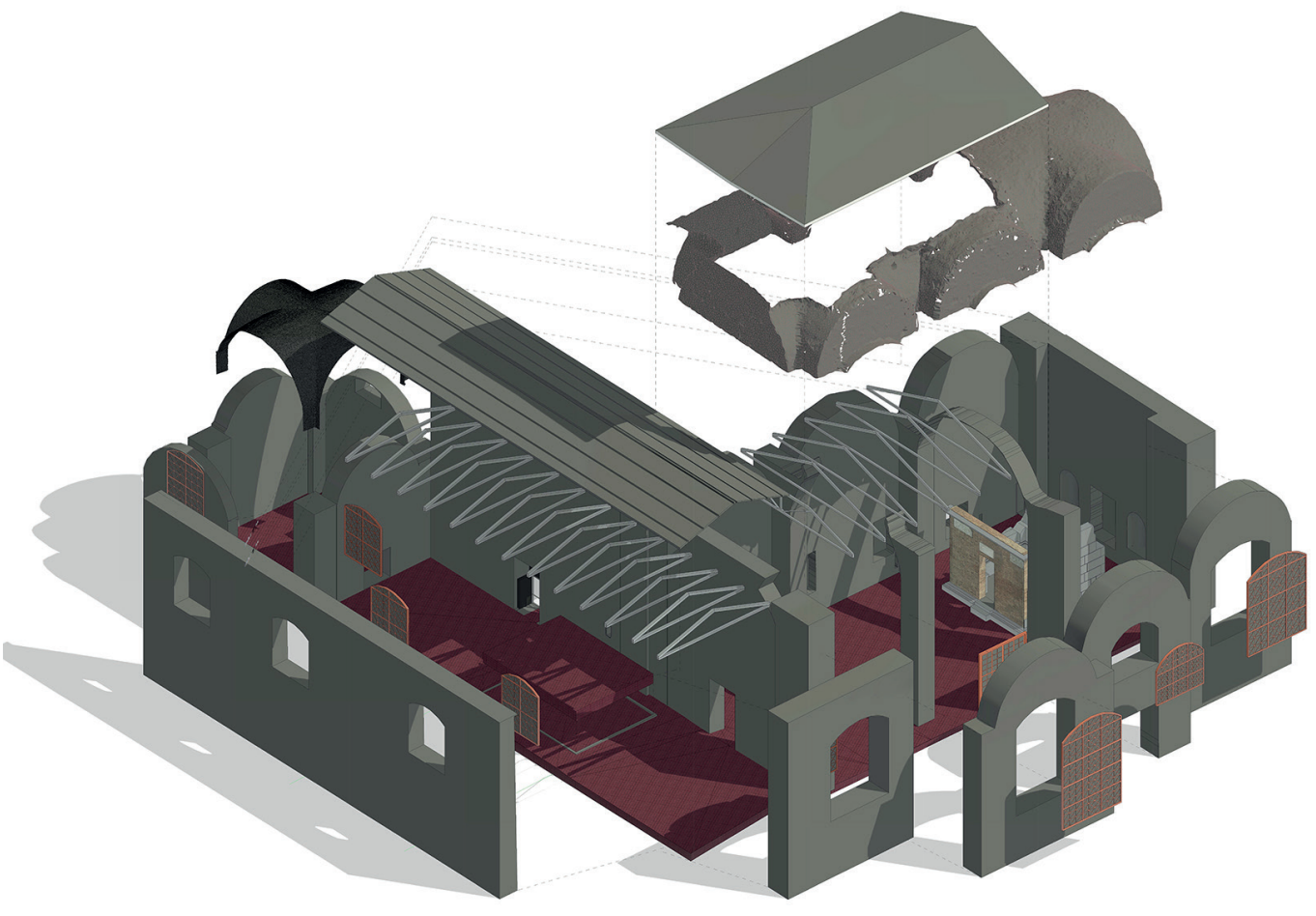

sary to define the appropriate level of detail (LOD) in order to reproduce a model which is similar to the original. The LoD strictly depends on the data collected and the different operational objectives foreseen. In the present work, the three-dimensional model has been built from a re-sampled point cloud, minimising the number of steps, avoiding lacks of accuracy, quality of data and details, and taking into account both building rules and proportional relations between the shapes.

Apart from offering a customizable geometric discretization, the multi-LoD approach makes it possible to select different display options, and so the representation of the objects, according to specific needs.

Considering the purpose of the A-BIM model, the local modelling was chosen which privileged the shapes over information scalability. In particular, the Hercules and Achelous mosaic, located in the room IX, and the Tomb of the Platorini have been modeled separately. In particular, for the latter an information link by means of relational data schemes was elaborated.

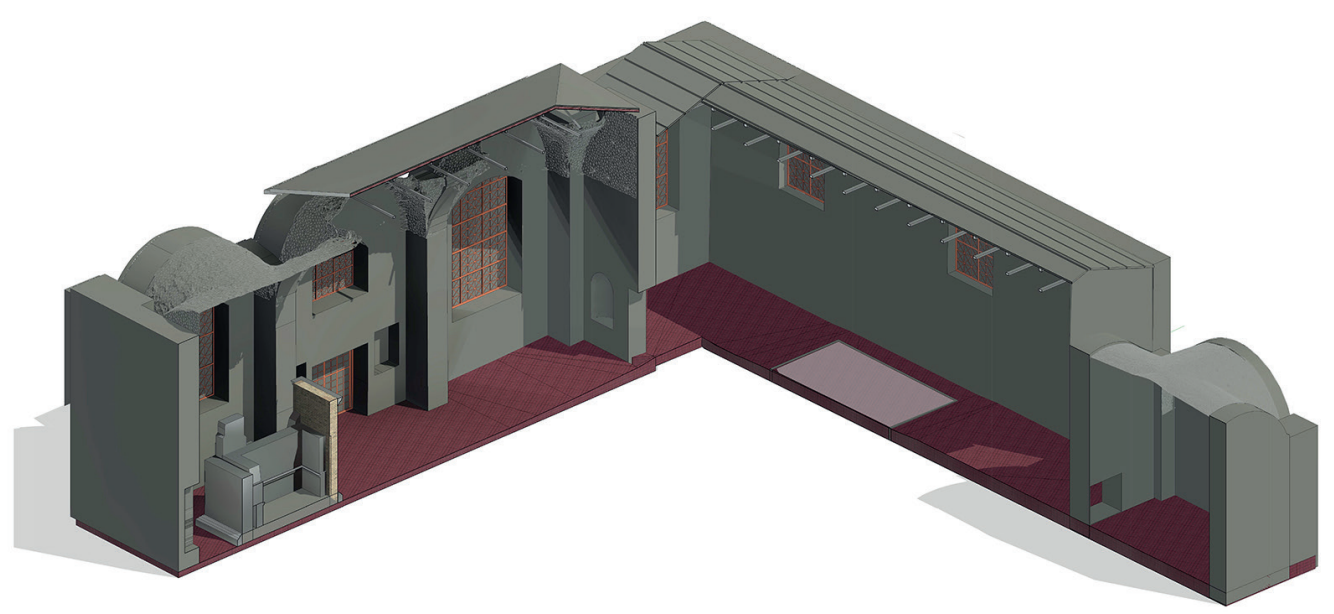


Fig. 6. Representation and compositing at different medium and high) of the Revit family of the Tomb of the Platorini.
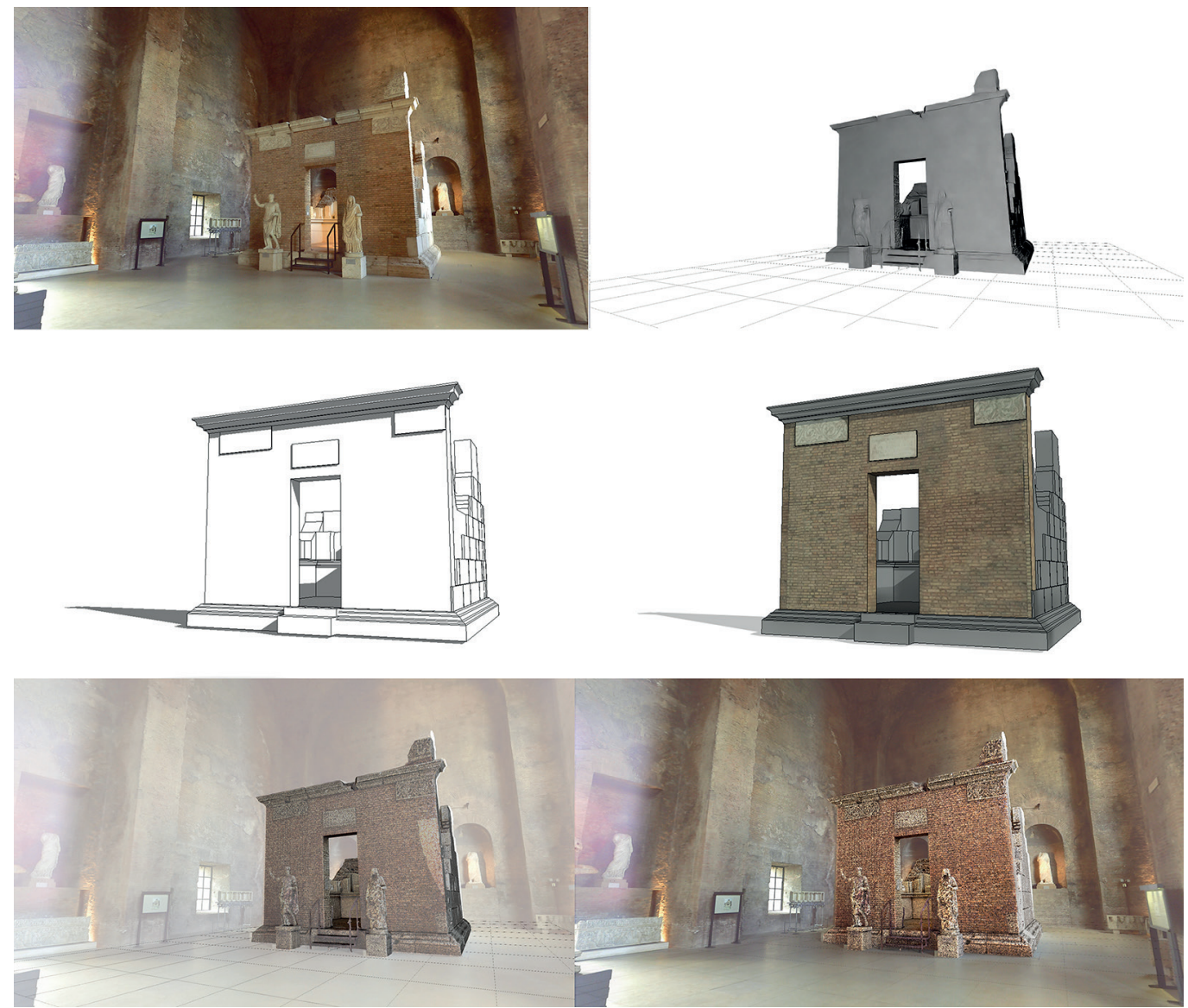

As to the irregular elements which constitute the remains of the barrel vault and the cross vault located respectively in the room $X$ and in the one adjacent to $X I$, it was decided to build a loadable family containing a polygonal reconstruction based on a LIDAR point cloud adopt the ball-pivoting algorithm [Bernardini, Claudio 1999, pp. 349-359], in order to leave the irregularity of morphology unchanged (figs. 4, 5).

For the Tomb of the Platorini, instead, the volumetric elements constituting the sepulchre were identified, designing in the same loadable family three different representations of the same elements, which can be activated selecting specific display options in BIMAuthoring Autodesk Revit ${ }^{\circledR}$. In particular, after choosing a low level of detail, architectural elements have been created from local models obtained by polygonal generators. Such elements, although maintaining a formal separation which allow the attribution of eventual specific information parameters, are characterized by an high representative simplification.

On the contrary, after setting a medium level of details, the loaded family displays a texturing of the outer layers of the volumes. Such texture was obtained elaborating a RGB mapping, extrapolated from the points matrix and optimized through the study of the local UV coordinates, preserving the appearance of the materials and the style of the objects.

Finally, after setting a high level of detail, the software automatically shows a third version of the Tomb, extrapolated from a polygonal mesh reconstructed from a point cloud after a process of decimation and optimization, and elaborated by CloudCompare and MeshLab (fig. 6).

The evaluation of the descriptive information to include in the A-BIM model (fig. 7) was carried out starting from the information sheets of the General Catalog of Cultural Heritage implemented with data concerning the survey, multimedia files and three-dimensional mesh reconstructions. The information entered concerns: the data of the object (name, location, type, function, etc.), the administrative geographical location (State, Region, address, etc.), the georeferencing (name of the excavation, period, etc.), the chronology (chronological contex, 
Fig. 7. Descriptive information included in the database associated with the A-BIM model.

Fig. 8. Database

connection in Microsoft Access format.
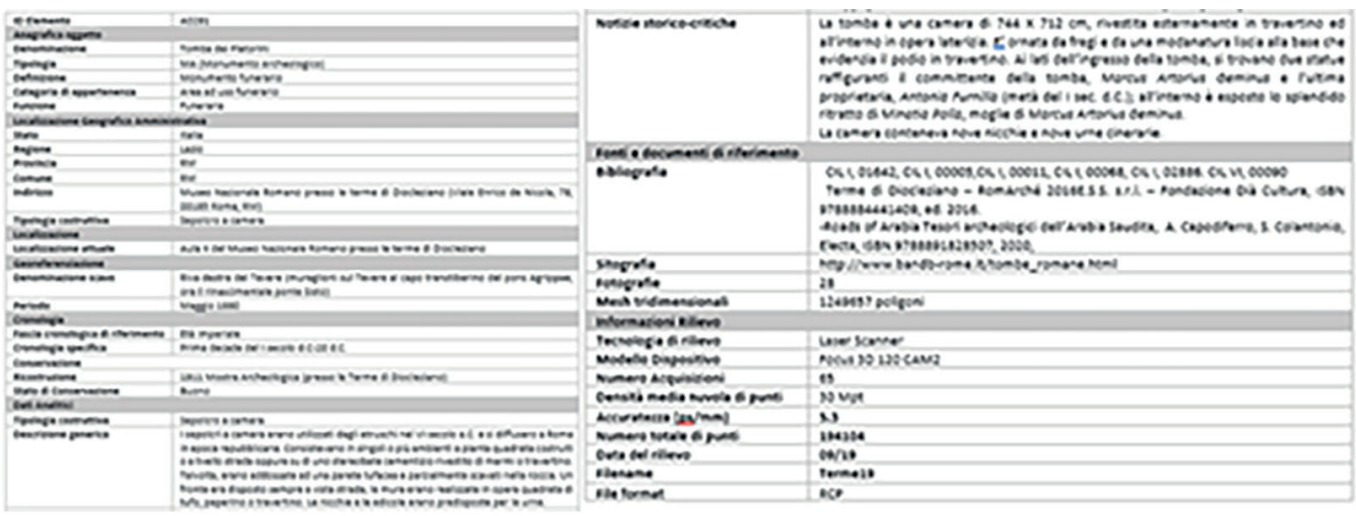

specific chronology, date of reconstruction, state of conservation, etc.), analytical data (type of construction, generic description, critical-historical information), sources and reference documents (bibliography, sitography, three-dimensional mesh, etc.), survey data (technology used, device model, number of acquisitions, etc.).

The relations between the model and the database was gathered thanks to ODBC (Open DataBase Connectivity), with the aim of guaranteeing an application independent from the data programming languages, connecting the Autodesk Revit ${ }^{\circledR}$ project to a Microsoft Access $^{{ }^{\circledR}}$ database, structured in charts and relations built on hierarchical cataloging schemes in XSD format (fig. 8).

This approach, in addition to allowing a standardized information organization, eventually interfaced with specific softwares, allows an indexed structurating of textual, graphic -more generally, information- resources. The connection between a single element of the 3D model and its informative base takes place thanks to an ID parameter, that can be recalled via SQL queries, thus guaranteeing the scalability and the customization of the data retrieval process.

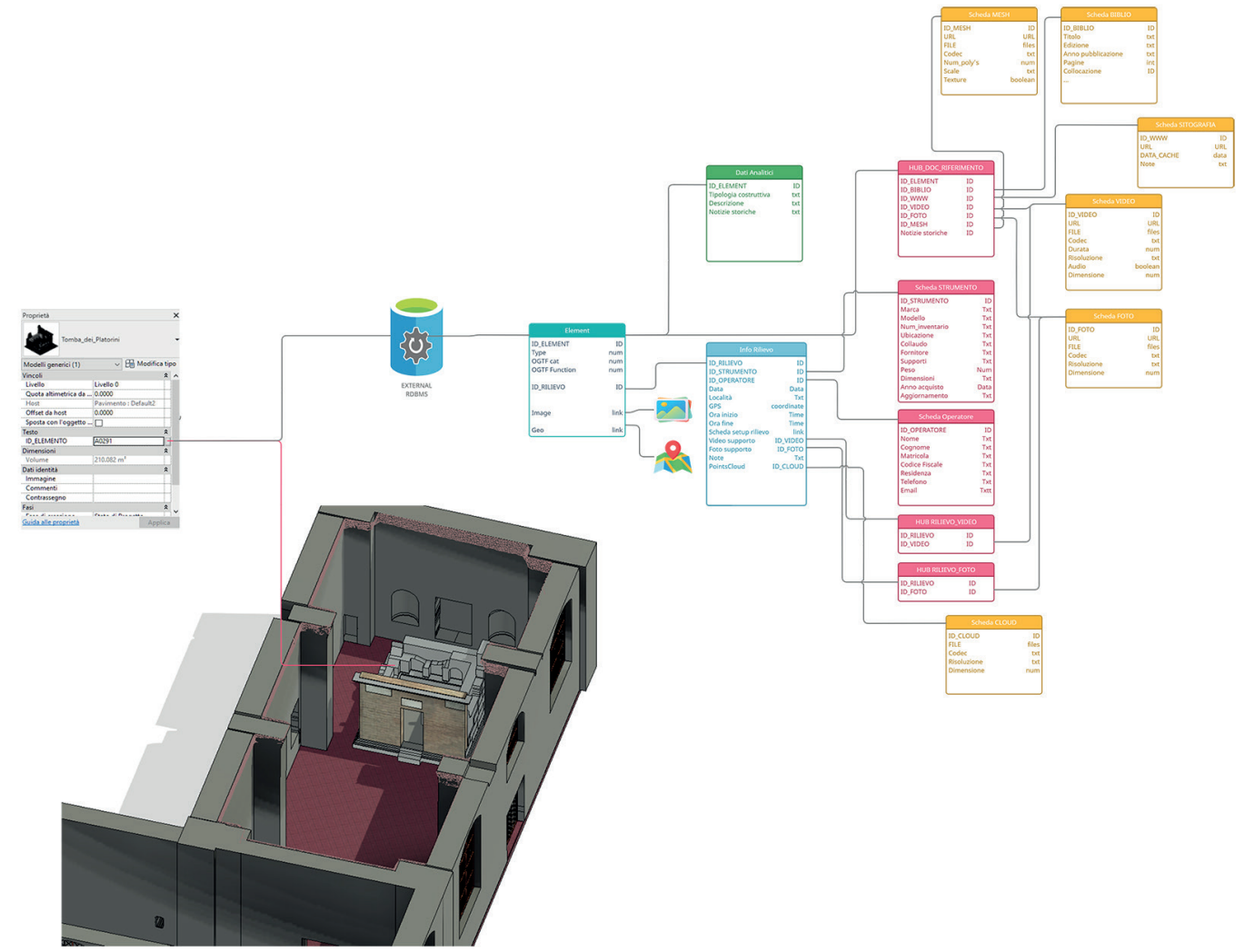


In this way, the BIM model becomes an 'hub' for accessing and reading all the related sources, through a hierarchical data organization that offers an efficient management of the storage space, enabling the reuse of files (a single file can be attributed to more than one object of the model) and the cross-platform saving (files can be saved in local hard-disk, NAS or online) (fig. 9).

\section{Conclusions}

In the present article we showed the implementation, using an A-BIM approach, of a three-dimensional model of a part of the Baths of Diocletian, characterized by an irregular and heterogeneous morphology. We concluded that the A-BIM is a trustworthy methodology for the representation of the built heritage, since it associates an high quality model to an accurate geometric representation, achievable at different levels of details, and, in addition, it is capable of creating connections with different kinds of data sets by exploiting different relational databases.

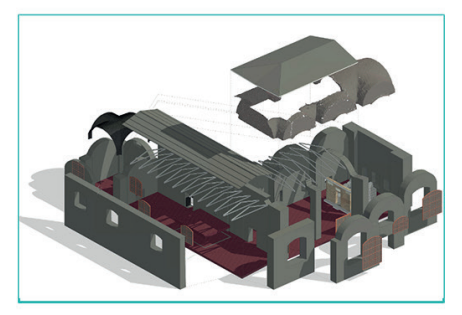

REVIT BIM FILE

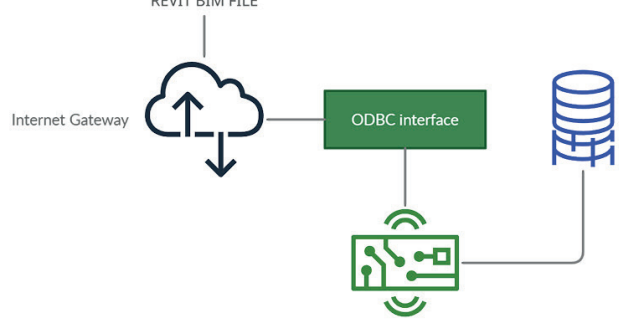

Fig. 9. Cross-platform use of the A-BIM model.
API Runtime DB Engine
Locale

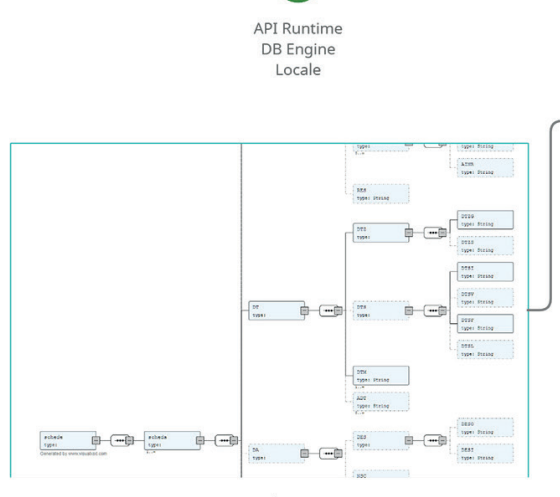

XSD Schema

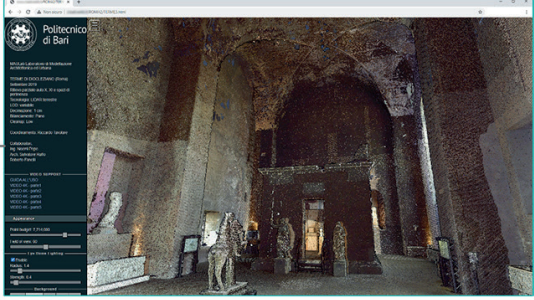

Web-based points cloud viewer

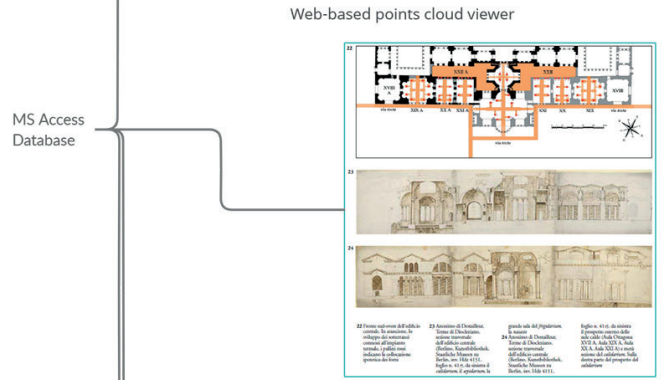

Documents

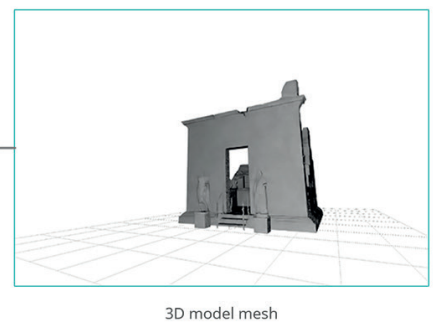

3D model mesh

Riferimenti bibliografici

Akca D., Remondino F., Novák D., Hanusch T., Schrotter,G., Gruen A. (2006). Recording and modeling of cultural heritage objects with coded structured light projection systems. In 2nd International Conference on Remote Sensing in Archaeology, March 20I5, pp. 375-382.

Banfi F. (2020). HBIM, 3D drawing and virtual reality for archaeological sites and ancient ruins. In Virtual Archaeology Review, II (23), pp. I6-33.

Bernardini F., Claudio S. (1999). The Ball-Pivoting Algorithm for Surface Reconstruction. In IEEE TRANSACTIONS ON VISUALIZATION AND COMPUTER GRAPHICS, pp. 349-359. 
Bosco A., D'Andrea A., Nuzzolo M., Pirelli R., Zanfagna P. (20 I 8). A Virtual Reconstruction of the Sun Temple of Niuserra: from Scans to ABIM Angela. In Oceans of Data Proceedings of the 44th Conference on Computer Applications and Quantitative Methods in Archaeology, pp. 377-388.

Bruno N. (2017). From Survey To Analysis for Cultural Heritage Management: A New Proposal for Database Design in Bim.

Bosco A., D'Andrea A., Nuzzolo M., Zanfagna P. (2019). A BIM APPROACH for the ANALYSIS of AN ARCHAEOLOGICAL MONUMENT. In ISPRS Annals of the Photogrammetry. Remote Sensing and Spatial Information Sciences, 42(2/W9), pp. I65- I 72.

Brusaporci S., Centofanti M., Continenza R., Trizio I. (2012). Sistemi Informativi Architettonici per la gestione, tutela e fruizione dell'edilizia storica. In ATTI I $6^{\circ}$ Conferenza Nazionale ASITA 20 I 2, pp. 3I 5-322.

Capparelli F., Camiz A. (2019). Bim Documentation for Architecture and Archeology: the Shipwreck Museum in the Kyrenia Castle, Cyprus. pp. 333-342. Roma: Gangemi Editore.

Chien S., Chuang T., Yu H.-S., Han Y., Soong B. H., Tseng K. J. (2017). Implementation of Cloud BIM-based Platform Towards High-performance Building Services. In Procedia Environmental Sciences, 38, pp. 436-444.

Croce V., Caroti G., De Luca L., Jacquot K., Piemonte A., Véron P. (202I). From the semantic point cloud to heritage-building information modeling: A semiautomatic approach exploiting machine learning. In Remote Sensing, I 3(3), pp. I-34.

Diara F., Rinaudo F. (2020). Building archaeology documentation and analysis through open source HBIM solutions via nurbs modelling. In International Archives of the Photogrammetry, Remote Sensing and Spatial Information Sciences - ISPRS Archives, 43(B2), pp. $1381-1388$.

Duguleană M., Carrozzino M., Gams M., Tanea I. (20I8).VR Technologies in Cultural Heritage Communications in Computer and Information Science (Vol. 904), pp. I-245.

Eastman C.M.C., Teicholz P., Sacks R., Liston K. (20I I). BIM Handbook: A Guide to Building Information Modeling for Owners, Managers, Designers, Engineers and Contractors (2nd Ed). John Wiley \& Sons, Inc. Hoboken, USA: John Wiley \& Sons Inc.

Forma Urbis (maggio 2016). Il Museo Nazionale Romano alle Terme di Diocleziano. RomArché 20 I6. Editoriale \& Sommario.

Negendahl K. (20I5). Building performance simulation in the early design stage: An introduction to integrated dynamic models In Automation in Construction, 54, pp. 39-53.

Pocobelli D.P., Boehm J., Bryan P., Still J., Bové J.G. (20I8). BIM for heritage science : a review. In Heritage Science, pp. 23-26.

Risbø| O., Gustavsen L. (20।8). LiDAR from drones employed for mapping archaeology - Potential, benefits and challenges. In Archaeological Prospection, 25(4), pp. 329-338.

Rodríguez-gonzálvez P., Muñoz-nieto A.L., Sanchez-Aparicio L.J. (20 I7). 4D reconstruction and visualization of cultural heritage : analyzing our legacy through time. In The International Archives of the Photogrammetry, Remote Sensing and Spatial Information Sciences, XLII (March), pp. I-3.

Templin T., Brzezinski G., Rawa M. (2019). Visualization of Spatiooral Building Changes Using 3D Web GIS. In IOP Conference Series: Earth and Environmental Science, 22I ( I), pp. I-I I.

Tomasello N., Cascone S.M., Russo G. (20I8). BIM for archaeological heritage : the case study of the Terme Romane dell' Indirizzo of Catania. June, pp. I- 13.

Vatan M., Selbesoglu M., \& Bayram B. (2009). The use of 3D laser scanning technology in preservation of historical structures. In Wiadomosci Konserwatorskie, 44, pp. 659-669.

Verdoscia C., Mongiello G., Musicco A., Tavolare R., Salomone A. (2020). 4D-HBIM for the conservation and valorization of cultural heritage. In World Heritage and Contamination, pp. I000-I008.

<http:/www.catalogo.beniculturali.it> (accessed 2021, February 23).

\section{Authors}

Cesare Verdoscia, Politecnico di Bari, cesare.verdoscia@poliba.it

Antonella Musicco, Politecnico di Bari, antonella.musicco@poliba.it

Michele Buldo, Politecnico di Bari, michele.buldo@poliba.it

Riccardo Tavolare, Politecnico di Bari, riccardo.tavolare@poliba.it

Noemi Pepe, Politecnico di Bari, pepenoemil@gmail.com

To cite this chapter.Verdoscia Cesare, Musicco Antonella, Buldo Michele, Tavolare Riccardo, Pepe Noemi (202I). La documentazione digitale del patrimonio costruito attraverso l' A-BIM. II caso studio delle Terme di Diocleziano, Roma/The Digital Documentation of Cultural Heritage through A-BIM. The Case Study of the Baths of Diocletian, Rome. In Arena A. Arena M. Mediati D. Raffa P. (a cura di). Connettere. Un disegno per annodare e tessere Lingugogi Distanze Tecnologie. Atti del $42^{\circ}$ Convegno Internazionale dei Docenti delle Discipline della Rappresentazione/Connecting. Drowing for weoving relationship. Languages Distances Technologies. Proceedings of the 42 th International Conference of Representation Disciplines Teachers. Milano: FrancoAngeli, pp. 2686-2703. 